OPEN ACCESS

Edited by:

Dieter Jahn,

Technische Universität Braunschweig,

Germany

Reviewed by:

Klaus Aktories,

University of Freiburg, Germany

Jozsef Soki,

University of Szeged, Hungary

*Correspondence:

Gerly A. C. Brito

gerlybrito@hotmail.com

Specialty section: This article was submitted to Infectious Diseases, a section of the journal

Frontiers in Microbiology

Received: 21 February 2020

Accepted: 28 July 2020

Published: 28 August 2020

Citation:

Martins CS, Costa DVS, Lima BB, Leitäo RFC, Freire GE, Silva GFM,

Pacífico DM, Abreu JG and Brito GAC

(2020) Clostridioides difficile

Toxin A-Induced Wnt/ $\beta$-Catenin

Pathway Inhibition Is Mediated by

Rac1 Glucosylation.

Front. Microbiol. 11:1998.

doi: 10.3389/fmicb.2020.01998

\section{Clostridioides difficile Toxin A-Induced Wnt//-Catenin Pathway Inhibition Is Mediated by Rac1 Glucosylation}

\author{
Conceição S. Martins ${ }^{1}$, Deiziane V. S. Costa ${ }^{2}$, Bruno B. Lima ${ }^{3}$, Renata F. C. Leitäo', \\ Gildênio E. Freire ${ }^{1}$, Guilherme F. M. Silva ${ }^{4}$, Dvison M. Pacífico ${ }^{4}$, José G. Abreu ${ }^{5}$ and \\ Gerly A. C. Brito ${ }^{1,2 *}$
}

\begin{abstract}
'Postgraduate Program in Morphofunctional Sciences, Department of Morphology, School of Medicine, Federal University of Ceará, Fortaleza, Brazil, 'Department of Physiology and Pharmacology, School of Medicine, Federal University of Ceará, Fortaleza, Brazil, ${ }^{3}$ Department of Medicine, Division of Cardiology, Emory University School of Medicine, Atlanta, GA, United States, ${ }^{4}$ Department of Medical Sciences, School of Medicine, Federal University of Ceará, Fortaleza, Brazil, ${ }^{5}$ Department of Anatomy, Institute of Biomedical Sciences, Federal University of Rio de Janeiro, Rio de Janeiro, Brazil
\end{abstract}

Clostridioides difficile toxin A ( TcdA) has been shown to inhibit cellular Wnt signaling, the major driving force behind the proliferation of epithelial cells in colonic crypts, likely through the inhibition of $\beta$-catenin nuclear translocation. Herein, we aimed to advance the understanding of this mechanism by replicating the findings in vivo and by investigating the specific role of Rac1, a member of the Rho GTPase family, on the inhibition of the Wnt-induced $\beta$-catenin nuclear translocation triggered by TcdA. To investigate the effects of TcdA on the Wnt/ $\beta$-catenin pathway in vivo, we injected the ileal loops of C57BL/6 mice with TcdA [phosphate-buffered saline (PBS) as the control] to induce C. difficile disease-like ileitis. After $4 \mathrm{~h}$ post-injection, we obtained ileum tissue samples to assess Wnt signaling activation and cell proliferation through Western blotting, immunohistochemistry, and $\mathrm{PPCR}$. To assess the role of Rac1 on Wnt signaling inhibition by TcdA, we transfected rat intestinal epithelial cells (IEC-6) with either a constitutively active Rac1 plasmid (pcDNA3EGFP-Rac1-Q61L) or an empty vector, which served as the control. We incubated these cells with Wnt3a-conditioned medium (Wnt3a-CM) to induce Wnt/ $\beta$-catenin pathway activation, and then challenged the cells with TcdA. We assessed Wnt signaling activation in vitro with TOP/FOPflash luciferase assays, determined nuclear $\beta$-catenin translocation by immunofluorescence, measured cyclin D1 protein expression by Western blotting, and quantified cell proliferation by Ki67 immunostaining. In vivo, TcdA decreased $\beta$-catenin, cyclin D1, and CMYC expression and inhibited the translocation of $\beta$-catenin into the nucleus in the ileum epithelial cells. In addition, TcdA suppressed cell proliferation and increased Wnt3a expression, but did not alter Rac1 gene expression in the ileum tissue. In vitro, constitutively active Rac1 prevented Wnt signaling inhibition by enabling the $\beta$-catenin nuclear translocation that had been blocked by TcdA. Our results show that TcdA inhibits Wnt/ $\beta$-catenin pathway in vivo and demonstrate that this inhibition is likely caused by a Rac1-mediated mechanism.

Keywords: Clostridioides difficile, Clostridioides difficile toxin A, Rac1, Wnt, $\beta$-catenin 


\section{INTRODUCTION}

Clostridioides difficile (C. difficile), a gram positive, spore forming anaerobic bacterium, is a major cause of nosocomial diarrhea (Zhu et al., 2018). The two major virulence factors responsible for C. difficile infection are C. difficile toxin A (TcdA) and C. difficile toxin $B(\operatorname{TcdB})$. TcdA and $T c d B$ enter cells through receptor-mediated endocytosis and inhibit the small Rho guanosine triphosphatases (GTPases), such as Rho, Racl, and Cdc42 (Chen et al., 2019). The Rho family of small GTPases is a branch within a superfamily of Ras-related small GTPases. Twenty mammalian genes encoding Rho GTPases have been identified of which Racl, Cdc42, and RhoA are the prototypes and therefore the best characterized (Jaffe and Hall, 2005). These signaling proteins regulate all the actin-dependent process like cell migration, phagocytosis, and cell contraction. They are also involved in various other signaling pathways, regulating gene expression, cell cycle, and apoptosis. Most Rho GTPases cycle between a GTP-bound active conformation and a GDP-bound inactive conformation (Wennerberg and Der, 2004), acting as molecular switches. Not surprisingly, this family of molecules plays central roles in maintenance of health, and their dysregulation often results in disease. Anomalous signaling of Rho GTPases is found in many human cancers and may be attributed to several mechanisms, such as overexpression of Rho GTPases with oncogenic activity or alterations of upstream regulators or downstream effectors (Vega and Ridley, 2008).

GTPases are known to be critically involved in the regulation of intestinal epithelial barrier functions, since inhibition of Rho GTPases results in actin cytoskeleton disruption, apoptosis, and impairment of intestinal cell proliferation (Welsh et al., 2001; Brito et al., 2002; Lica et al., 2011; D’Auria et al., 2012; Chen et al., 2019). Most of these cellular processes are also regulated by the activated $\mathrm{Wnt} / \beta$-catenin signaling pathway (Gao et al., 2017; Steinhart and Angers, 2018). A previous study from our research group showed that $\mathrm{TcdA}$ inhibits the Wnt/ $\beta$-catenin signaling pathway in intestinal epithelial cells (IECs; Lima et al., 2014); however, its mechanism remains unknown.

The Wnt/ $\beta$-catenin signaling pathway is a well-conserved and complex signaling cascade that plays an important role in development, homeostasis, and disease (Gough, 2012; Tortelote et al., 2017). This signaling pathway dictates intestinal epithelial layer self-renewal through a complex cellular process that includes cell proliferation, cell differentiation, and apoptosis (Ring et al., 2014). Pathway activation depends on the secretion of Wnt family proteins, which in turn bind to frizzled (FZD) receptors and low-density receptor-related protein (LRP) 5/6 coreceptors on the cell membrane (Wu et al., 2009). In the absence of Wnt ligands, the level of intracellular $\beta$-catenin is regulated by a multiprotein cytoplasmic degradation complex that consists of Axin and its interacting partners: tumor suppressor adenomatous polyposis coli (APC), glycogen synthase kinase 3 beta (GSK3 $\beta$ ), and casein kinase 1 (CK1; Ring et al., 2014). The destruction complex phosphorylates $\beta$-catenin, leading to subsequent proteasomal degradation. When Wnt ligands bind their FZD and LRP5/6 receptors, the destruction complex is disassembled, allowing for $\beta$-catenin accumulation in the cytoplasm and its translocation to the nucleus. Then, nuclear $\beta$-catenin binds to the transcription factors of the $\mathrm{T}$ cell factor/lymphocyte enhancer factor (TCF/LEF) family (Kimelman and Xu, 2006; Ring et al., 2014) and promotes the transcription of Wnt/ $\beta$-catenin pathway target genes, including $c M Y C$, cyclin D1, survivin, bcl-2, Rac1, Rho, and Cdc42 (Daniels and Weis, 2005; Lima et al., 2014).

Previous studies demonstrated that both TcdA and TcdB inhibit the Wnt/ $\beta$-catenin pathway. Whereas TcdB inhibits this pathway by binding to the frizzled-7 (FZD-7) receptor in the colonic epithelium (Tao et al., 2016; Chen et al., 2019). However, whether TcdA impairs Wnt/ $\beta$-catenin signaling transduction in vivo and the mechanism underlying its inhibitory action remain unknown. Given that Racl plays an important role in $\beta$-catenin translocation to the nucleus, we hypothesized that its inactivation by $\mathrm{TcdA}$ is crucial for $\mathrm{Wnt} / \beta$-catenin signaling inhibition. Here, we investigated the role of Racl in the TcdAmediated inhibition of the Wnt/ $\beta$-catenin signaling pathway in IECs in vitro and characterized the impact of TcdA on Wnt $/ \beta$-catenin signaling in a mouse ileal loop model.

\section{MATERIALS AND METHODS}

\section{Animals}

All experimental protocols were approved by the Federal University of Ceará Committee on the Ethical Treatment of Research Animals (CEUA. N. 2727150218) and were performed in accordance with the Guide for Care and Use of Laboratory Animals (National Institutes of Health, Bethesda, MD, United States). Male C57BL/6 mice (8 weeks old) were obtained from the vivarium of the Department of Physiology and Pharmacology of the Federal University of Ceará. The mice were maintained in a temperature-controlled environment $\left(22 \pm 1^{\circ} \mathrm{C}\right)$ with a 12 -h light/dark cycle and had a free access to drinking water and standard diet.

\section{Clostridioides difficile Toxin A-Induced Ileitis}

TcdA-induced murine ileitis was induced as previously described (De Araújo Junqueira et al., 2011) with some modifications. Mice ( $n=6$ in each group) were fasted for $4 \mathrm{~h}$ and had a free access to water before being anesthetized $(80 \mathrm{mg} / \mathrm{kg}$ ketamine and $10 \mathrm{mg} / \mathrm{kg}$ xylazine administered intraperitoneally). After midline laparotomy, a $4-\mathrm{cm}$ ileal loop was ligated, and $10 \mu \mathrm{g}$ of TcdA (TechLab) in $200 \mu \mathrm{l}$ of phosphate-buffered saline (PBS) was injected at the site of the ligations. Control loops were injected with only $200 \mu \mathrm{l}$ of PBS. After $4 \mathrm{~h}$, the mice were euthanized $(240 \mathrm{mg} / \mathrm{kg}$ ketamine and $15 \mathrm{mg} / \mathrm{kg}$ xylazine administered intraperitoneally), and the ileal loops were removed for subsequent analysis of the parameters defined in this study.

\section{Quantitative Real-Time PCR}

Quantitative real-time PCR (qPCR) analysis of the gene expression of $\beta$-catenin, cyclin D1, cMYC, Wnt3a, and Rac1 was performed in mouse ileum tissue stored in RNAlater solution (Qiagen), an RNA stabilizer, at $-80^{\circ} \mathrm{C}$. Total RNA was extracted by an 
RNA isolation system (Promega) according to the manufacturer's protocol. The RNA was quantified by a NanoDrop spectrometer (Thermo Fisher Scientific), and RNA quality was determined by examining the $260 / 280$ ratio $>1.8$. A total of $1 \mu \mathrm{g}$ RNA was then reverse transcribed using a high-capacity cDNA reverse transcription kit (Applied Biosystems) according to the manufacturer's protocol. qPCR was performed using SYBR Green PCR Master Mix (Applied Biosystems), as described in the manufacturer's instructions. The sequences of the primers are listed in Table 1. To compare gene expression under different conditions, the expression under each condition (normalized to $\mathrm{GAPDH}$, the endogenous control) was quantified relative to the control condition. For $\beta$-catenin, cyclin D1, cMYC, Wnt3a, and Rac1, qPCR amplification was performed in a CFX Connect system (Bio-Rad) under the following conditions: $50^{\circ} \mathrm{C}$ for $2 \mathrm{~min}$ and $95^{\circ} \mathrm{C}$ for $10 \mathrm{~min}$, followed by 40 cycles of $95^{\circ} \mathrm{C}$ for $15 \mathrm{~s}$ and $60^{\circ} \mathrm{C}$ for $60 \mathrm{~s}$. The relative expression levels of the genes were calculated using the threshold cycle $\left(2^{-\Delta \Delta \mathrm{CT}}\right)$ method (Livak and Schmittgen, 2001).

\section{Measurement of Nuclear $\beta$-Catenin by Western Blotting}

To obtain the nuclear extract from the ileum tissue samples, a nuclear extract kit (Abcam) was used according to the manufacturer's protocol. Protein concentrations were determined through bicinchoninic acid assay according to the protocol of the kit manufacturer (Thermo Fisher Scientific). Fifty micrograms of reduced protein in Laemmli sample buffer with $\beta$-mercaptoethanol (Bio-Rad) was run on an SDS-PAGE gel (10\%) and transferred onto PVDF membrane for $2 \mathrm{~h}$. Then, the membranes were blocked with $5 \%$ blotting-grade blocker (Bio-Rad) for $1 \mathrm{~h}$ at room temperature and incubated overnight with anti- $\beta$-catenin (Abcam, 1:200) and anti-B23 (Santa Cruz Biotechnology, $1: 1000)$ at $4^{\circ} \mathrm{C}$. Then, the membranes were incubated with secondary antibody conjugated with horseradish peroxidase (HRP; Invitrogen, 1:1000) for $2 \mathrm{~h}$ at room temperature. The fluorescence of a chemiluminescent signal system was detected by a ChemiDoc ${ }^{\mathrm{TM}}$ XRS+ system (Bio-Rad, Life Technologies), and the bands were quantified by densitometry using Image Lab 5.0 software (Bio-Rad).

\section{Immunohistochemistry Assay for $\beta$-Catenin, Cyclin D1, cMYC, Ki67, and Wnt3a}

Sections $(4 \mu \mathrm{m}$ thick) were prepared from paraffin-embedded ileum tissue. Then, the samples were deparaffinized, dehydrated, immersed in retrieval solution (DAKO, $\mathrm{pH} 6.0$ or $\mathrm{pH} 9.0$ ) for

TABLE 1 | Primers used in qPCR.

\begin{tabular}{lll}
\hline Gene & Forward & Reverse \\
\hline$\beta$-catenin & ACGCACCATGCAGGAATACA & CTTAAGATGGCCAGCAAGC \\
Cyclin D1 & GCGTACCCTGACACCAATCT & AATCTCCTTCTGCACGCACT' \\
CMYC & AGCTGCTTCGCCTAGAATT & 'CCTATTCAGCACGCTTCTCC \\
Wnt3a & TTCTTACTTGAGGGCGCAGA & AAGGAACCCAGATCCCAAAT \\
Rac1 & GACCAGCCGACTAGCTITG3 & CAGCACACCCACAACTAGGA \\
GAPDH & AGAACATCATCCCTGCATCC & CACATTGGGGGTAGGACAC
\end{tabular}

30 min in PT Link (DAKO), incubated with 3\% (v/v) hydrogen peroxide to block endogenous peroxidase for $20 \mathrm{~min}$ at room temperature, and washed in PBS. The sections were then incubated with $\beta$-catenin (Abcam, 1:400), cyclin D1 (DAKO Flex), cMYC (Abcam, 1:200), Ki67 (Abcam, 1:200), and Wnt3a (Invitrogen, 1:800) antibodies diluted in diluent antibody solution (DAKO) for $1 \mathrm{~h}$ at room temperature. Next, the sections were washed with wash buffer and incubated with polymer (HRP $\mathrm{DAKO})$ for $30 \mathrm{~min}$. The slides were then washed and stained with chromogen 3,3'-diaminobenzidine peroxide (DAB), followed by counterstaining with Mayer's hematoxylin, dehydrated in a graded alcohol series, cleared with xylene, and placed on a coverslip. The negative controls were processed simultaneously as described above, with the primary antibody being replaced by the diluent antibody. The images were captured by means of a light microscope coupled to a camera with an LAZ 3,5 acquisition system (LEICA DM1000, Germany). One hundred epithelial cells were counted from each field to quantify the percentage of cells showing positive immunostaining for each protein.

\section{Cell Culture, Transfection and Wnt3a- Conditioned Medium Production}

The rat intestinal epithelial cell (IEC-6) line was obtained from the repository of cells in Rio de Janeiro. IEC-6 cells were cultured in Dulbecco's Modified Eagle's Medium (DMEM, Gibco) supplemented with $10 \%$ fetal bovine serum (FBS), $1 \%$ antibiotics $(100 \mu \mathrm{g} / \mathrm{ml}$ penicillin and $100 \mu \mathrm{g} / \mathrm{ml}$ streptomycin, Gibco) and $0.1 \mathrm{U} / \mathrm{ml}$ bovine insulin (Sigma) at $37^{\circ} \mathrm{C}$ in a humidified incubator under $5 \% \mathrm{CO}_{2}$ conditions for $21-30$ passages. For all the experiments, the IEC-6 cells were released using $0.25 \%$ trypsin-EDTA for $5 \mathrm{~min}$.

The IEC-6 cells were transfected with pcDNA3-EGFP-Rac1Q61L [Addgene, the vector pcDNA3 contains the mutant Rac1 encoding cDNA (Racl) in its active form and the green fluorescent protein (GFP); Subauste et al., 2000] or an empty vector with Lipofectamine 3000 reagent (Thermo Scientific), as described in the manufacturer's instructions. After $18 \mathrm{~h}$, the transfection medium was removed, and the cells were incubated with 50\% Wnt3a-conditioned medium (Wnt3a-CM) and/or TcdA (TechLab, $50 \mathrm{ng} / \mathrm{ml}$ ). Then, after $24 \mathrm{~h}$ of incubation, the cells were collected for evaluation.

Wnt3a-CM was obtained from L cells stably transfected with the Wnt3a plasmid cultured in DMEM supplemented with $10 \%$ FBS for 4 days. The medium was collected and filtered using a $0.22 \mu \mathrm{m}$ filter, and fresh medium was added to the cells and cultured for 3 more days. After this period, the medium was collected and mixed with the previous medium at a 1:1 ratio. As a control, the CM was similarly generated with an untransfected parental cell line.

\section{TCF Reporter Assay}

The IEC-6 cells were cotransfected with TOPflash (Millipore)/ FOPflash (Millipore) and the pRL-TK vector (Promega) in combination with the pcDNA3-EGFP-Rac1-Q61 or an empty vector with Lipofectamine 3000 reagent (Thermo Scientific) 
according to the reagent manufacturer's instructions. TOPflash is a TCF reporter plasmid containing two sets of three copies of wild-type TCF-binding sites and is driven by a minimal promoter of thymidine kinase inserted upstream of the luciferase reporter gene. FOPflash contains mutated TCF-binding sites driven by the same thymidine kinase promoter and upstream luciferase open reading frame as used in TOPflash. FOPflash is used as a negative control for TOPflash activity. The pRL-TK vector contains the Renilla gene under the control of the constitutively active herpes simplex virus thymidine kinase promoter and was used as a normalizer (MAJOR, 007; Kumar, 2008). After transfection, the medium was removed, and 50\% Wnt3a-CM with or without TcdA was added to the cells and incubated for 24 h. Next, the cells were lysed, and luciferase and Renilla activities were measured by a dual-luciferase reporter system (Promega) with a microplate luminometer. This assay is as a gold standard to evaluate $\beta$-catenin translocation into the nucleus.

\section{Immunofluorescence Staining and Confocal Microscopy}

Immunofluorescence assays were performed as previously described (Lima et al., 2014). Briefly, IEC-6 cells were fixed in $4 \%$ paraformaldehyde in $\mathrm{PBS}$ at $\mathrm{pH} 7.6$, washed with $\mathrm{PBS}$, and permeabilized with $0.1 \%$ Triton X-100 in PBS for $5 \mathrm{~min}$. The samples were then blocked for $1 \mathrm{~h}$ with PBS containing $5 \%$ bovine serum albumin (BSA). The cells were incubated with an anti- $\beta$-catenin antibody (1:200, Abcam) overnight at $4^{\circ} \mathrm{C}$, and a secondary antibody conjugated with Alexa Fluor 596 (1:1000) for $1 \mathrm{~h}$ at room temperature. Then, the cells were incubated with 4',6-diamidino-2-phenylindole (DAPI, Thermo Scientific) for $5 \mathrm{~min}$, washed with PBS, and mounted with Prolong Gold mounting medium (Thermo Scientific). Images were captured using a CoolSNAP-Pro digital camera (Media Cybernetics, Bethesda, MD, United States). The percentage of cells showing positive immunostaining for $\beta$-catenin in the nucleus or cytoplasm and the percentage of unstained cells were determined by counting 100 DAPIstained nuclei.

\section{Measurement of IEC-6 Cell Proliferation}

IEC-6 cell proliferation was evaluated by Ki67 immunocytochemistry, as previously described by TinocoVeras et al. (2017). Briefly, $3 \times 10^{5}$ cells/well in a 24 -well plate were fixed with $4 \%$ paraformaldehyde solution for $30 \mathrm{~min}$, washed with PBS, and permeabilized with $0.1 \%$ Triton X-100 for $5 \mathrm{~min}$. The samples were then blocked for $1 \mathrm{~h}$ with $5 \%$ BSA and incubated with anti-Ki67 antibody (1: 200, Abcam) for $1 \mathrm{~h}$ at room temperature. The samples were then incubated with the HRP polymer (DAKO) for $30 \mathrm{~min}$ at room temperature. Then, the cells were stained with DAB chromogen (DAKO) and counterstained with hematoxylin. The coverslips were placed on slides using Faramount (DAKO). The percentage of cells showing positive immunostaining for Ki67 was determined by counting 100 hematoxylin-stained nuclei.

\section{Western Blot Analysis}

Lysate samples from the treated IEC-6 cells were harvested in RIPA buffer (Thermo Scientific) by the procedure described by the manufacturer. Protein concentrations were determined through bicinchoninic acid assay according to the protocol of the kit manufacturer (Thermo Fisher Scientific). Thirty micrograms of reduced protein in Laemmli sample buffer with $\beta$-mercaptoethanol (Bio-Rad) was run on an SDS-PAGE gel (10\%) and transferred onto PVDF membrane for $2 \mathrm{~h}$. Then, the membranes were blocked with $5 \%$ blotting-grade blocker (Bio-Rad) for $1 \mathrm{~h}$ at room temperature and incubated overnight with anti-cyclin D1 (Abcam, ab32572, 1:200), anti-Rac1 (BD Bioscience, 610651, 1:500), and anti- $\beta$-actin (Santa Cruz Biotechnology, $1: 1000)$ at $4^{\circ} \mathrm{C}$. Then, the membranes were incubated with secondary antibody conjugated with HRP (Invitrogen, 1:1000) for $2 \mathrm{~h}$ at room temperature. The fluorescence of a chemiluminescent signal system was detected by a ChemiDoc $^{\mathrm{TM}}$ XRS+ system (Bio-Rad, Life Technologies), and the bands were quantified by densitometry using Image Lab 5.0 software (Bio-Rad).

\section{Statistical Analysis}

All quantitative results are expressed as the means \pm standard error of the mean (SEM). Statistical analysis of the data was performed using GraphPad Prism software, version 6.0. Student's $t$-tests were used to compare two groups, and analyses of variance (ANOVAs) followed by Bonferroni's multiple comparison test were used for comparisons of more than two groups. A value of $p<0.05$ was considered significant.

\section{RESULTS}

\section{TcdA Inhibits Wnt/ $\beta$-Catenin Signaling in vivo}

Given that TcdA had previously been shown to inhibit Wnt $\beta$ catenin signaling in the IEC-6 cells (Lima et al., 2014), we asked whether Wnt/ $\beta$-catenin signaling could be inhibited in a mouse model of TcdA-induced ileitis, particularly since epithelial cells interact with other cells in vivo. We found that TcdA downregulated $(p<0.02) \beta$-catenin gene expression in ileum tissue compared to the level in the control (Figure 1A). Similarly, $\beta$-catenin protein expression in the TcdA-challenged ileum tissue was notably reduced compared to that in control ileal tissue (Figure 1B). TcdA reduced the levels of $\beta$-catenin protein in the epithelial cell nuclei from ileal crypts (Figure 1C).

Nuclear translocation of $\beta$-catenin activates TCF4, leading to the transcription of target genes, such as $c M Y C$ and cyclin D1 (Chen et al., 2019). To analyze whether TcdA-induced inhibition of $\beta$-catenin nuclear translocation alters cMYC and cyclin D1 expression in the ilea of the mice, we performed a qPCR analysis of these genes. Notably, TcdA decreased cMYC $(p<0.02)$ and cyclin D1 $(p<0.04)$ gene expression in the ilea of the treated mice compared to that in the ilea of the control group mice (Figures 2A,B). As observed in Figure 2C, TcdA reduced $(p<0.0001)$ cyclin D1 


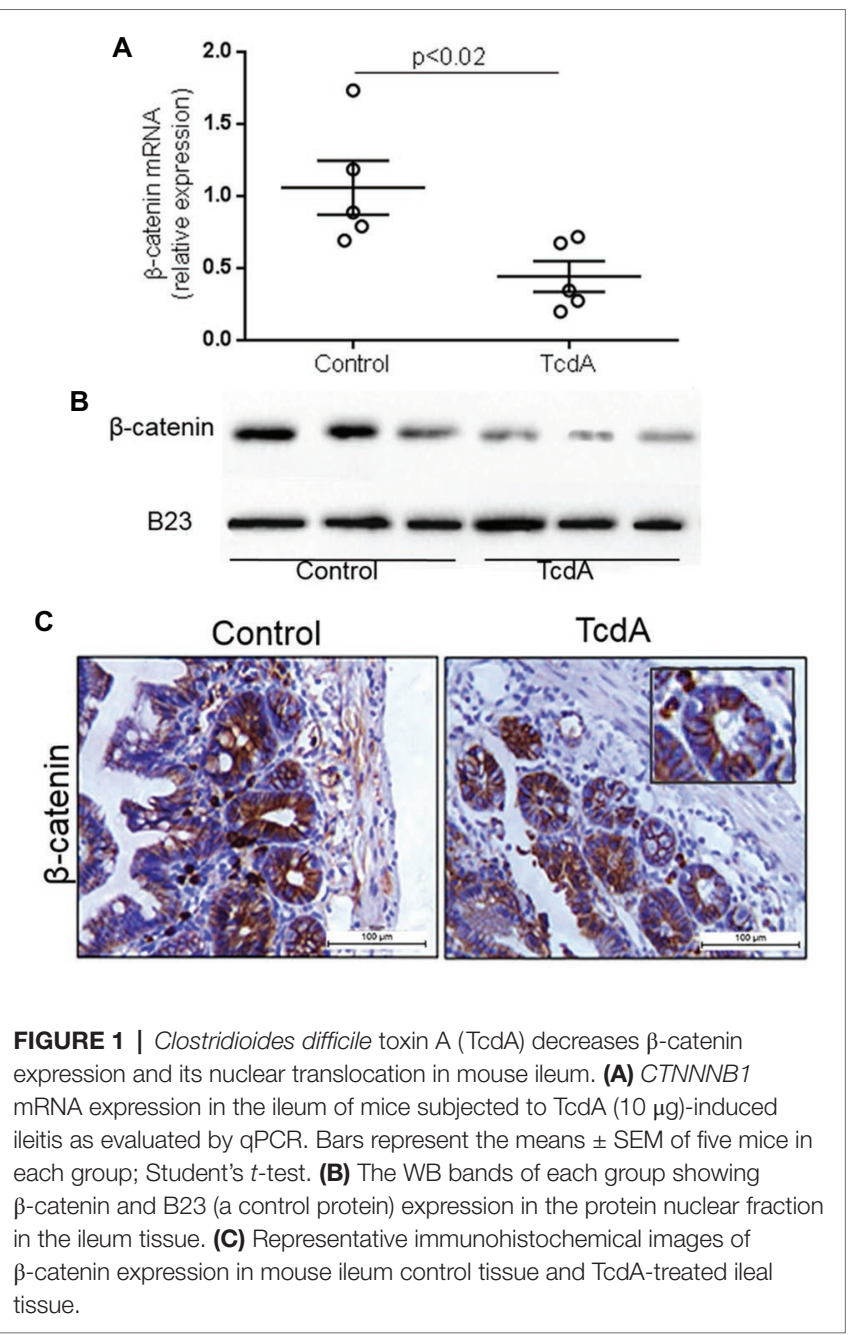

immunostaining in the ilea of the treated mice compared to that in the ilea of the control group mice. In the mouse ileum, cyclin D1 is mainly expressed by epithelial cells from ileal crypts (Figure 2D). TcdA also decreased $(p<0.0001)$ the number of cells showing cMYC immunostaining in the ilea of the treated mice compared to the number in the ilea of the control group mice (Figure 2E). As cyclin D1, cMYC is predominantly expressed by cells in ileal crypts in normal tissues, and its expression is reduced by challenge with TcdA (Figure 2F). These results are consistent with those showing Wnt $/ \beta$-catenin target gene inhibition by TcdA and may indicate TcdA influence on cell proliferation.

\section{TcdA Decreases Cell Proliferation in Mouse Ileal Crypts}

Because cMYC and cyclin D1 are proteins related to the cell proliferation cycle, we used Ki67 immunohistochemistry to evaluate whether TcdA is able to alter cell proliferation in the ileal crypts. We found that TcdA decreased the percentage of Ki67-positive cells in the ileal crypts of the treated mice compared with the percentage in the crypts of the control mice
( $p<0.0001$; Figure 3A). In the control mice, a greater number of Ki67-positive cells were found in intestinal crypts (Figure 3B), and they were considerably reduced by TcdA (Figure 3B).

\section{TcdA Upregulates Wnt3a in the Mouse Ileum}

Given that Wnt3a is an endogenous agonist that stimulates $\beta$-catenin translocation resulting in proliferation, we asked whether TcdA could affect its expression in the mouse ileum. We found that TcdA upregulated Wnt3a gene expression in the ilea of the treated mice compared to that in the ilea of the control group mice $(p<0.01$; Figure $4 \mathrm{~A})$. TcdA increased Wnt3a protein expression in the epithelial cells (Figure 4B).

\section{TcdA Inhibition of $\beta$-Catenin Nuclear Translocation Induced by Wnt3a Is Reversed by Upregulation of Rac1 in the Epithelial Cells in vitro}

Previously, it was demonstrated that Wnt3a does not affect TcdA-induced $\beta$-catenin nuclear translocation inhibition (Lima et al., 2014). Because TcdA glucosylates Rho GTPases, such as Racl (without affecting Racl gene expression in vivo, as shown in Supplementary Figure 1), which induces the recruitment of $\beta$-catenin to the nucleus (Wu et al., 2008; Pethe et al., 2011; Jamieson et al., 2015), we investigated whether upregulation of Racl through transfection of pcDNA3-EGFP-Rac1-Q61L (as shown in Supplementary Figures 2,3) could recover Wnt3a-induced $\beta$-catenin nuclear translocation in the intestinal epithelial (IEC-6) cells challenged with TcdA. We found that Wnt3a alone induced $\beta$-catenin nuclear activity in a manner independent of pcDNA3-EGFPRac1-Q61L transfection in the IEC-6 cells, while its transcriptional regulatory response (as demonstrated by the TOPflash/FOPflash, ratio) was inhibited by TcdA with either Wnt3a or Rac1 upregulation alone. Rac1 upregulation in the presence of Wnt3a-CM increased $\beta$-catenin nuclear activity in the IEC- 6 cells challenged with $\operatorname{TcdA}(p<0.001$; Figure 5A). As observed in Figures 5B,C, in the IEC-6 cells transfected with pcDNA3-EGFP-Rac1-Q61L, Wnt3a alone increased the level of $\beta$-catenin immunostaining in the nucleus, and TcdA decreased the nuclear immunostaining in this epithelial cell line. Notably, Racl upregulation in the presence of Wnt3a-CM induced increased the level of $\beta$-catenin immunostaining in the nuclei of the IEC-6 cells challenged with TcdA (Figures 5B,C). As expected, the increased expression of Rac1 caused by transfection with pcDNA3-EGFP-Rac1-Q61L reversed the inhibitory effect of TcdA on cyclin D1 protein expression in the IEC-6 cells induced by Wnt3a compared with the expression in the IEC- 6 cells transfected with pcDNA (empty vector) and incubated with TcdA and Wnt3a (Figures 5D,E).

\section{TcdA-Induced Inhibition of IEC-6 Cell Proliferation Is Recovered by the Upregulation of Rac1}

Given that activation of the Wnt/ $\beta$-catenin pathway results in cell proliferation and that TcdA inhibits the proliferation of 

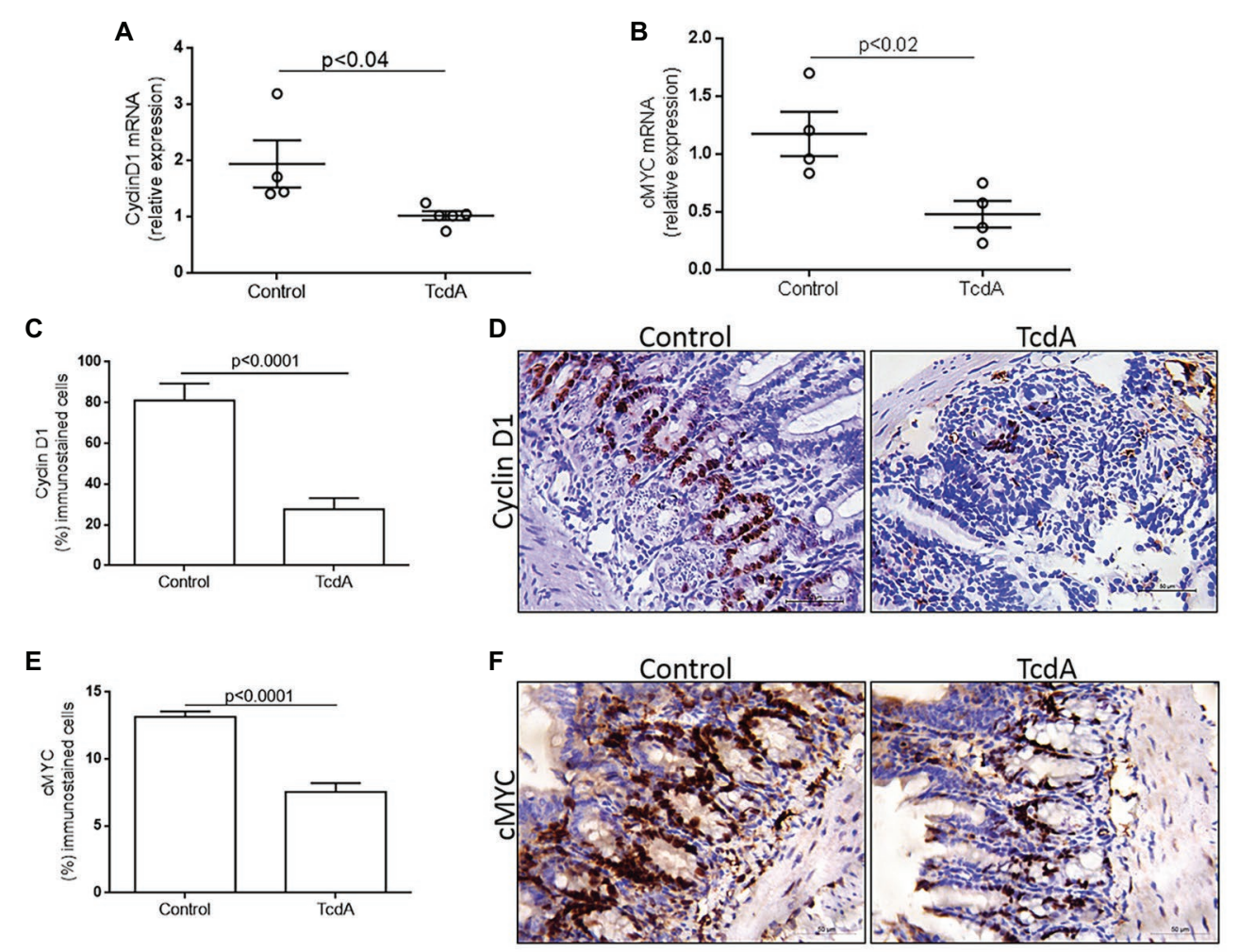

FIGURE 2 | TcdA downregulates $\beta$-catenin target genes (CMYC and cyclin D1) and reduces cyclin D1 protein in the ileum of the treated mice. (A) CCND1 and (B) CMYC mRNA expression in the ileum of mice treated with phosphate-buffered saline (PBS; control) or TcdA (10 $\mu \mathrm{g})$ for $4 \mathrm{~h}$, as evaluated by qPCR. Bars represent the means \pm SEM of five mice in each group; Student's $t$-test. (C) Percentage of the cells showing positive cyclin D1 immunostaining. Data are the means \pm SEM; Student's $t$-test. (D) Representative immunohistochemical images of cyclin D1 levels in the ilea of mice challenged with PBS (control) or TcdA (10 $\mu \mathrm{g})$. (E) Percentage of the cells showing positive CMYC immunostaining. Data are the means \pm SEM; Student's $t$-test. (F) Representative immunohistochemical images of cMYC expression in mouse ilea challenged with PBS (control) or TcdA (10 $\mu \mathrm{g})$.

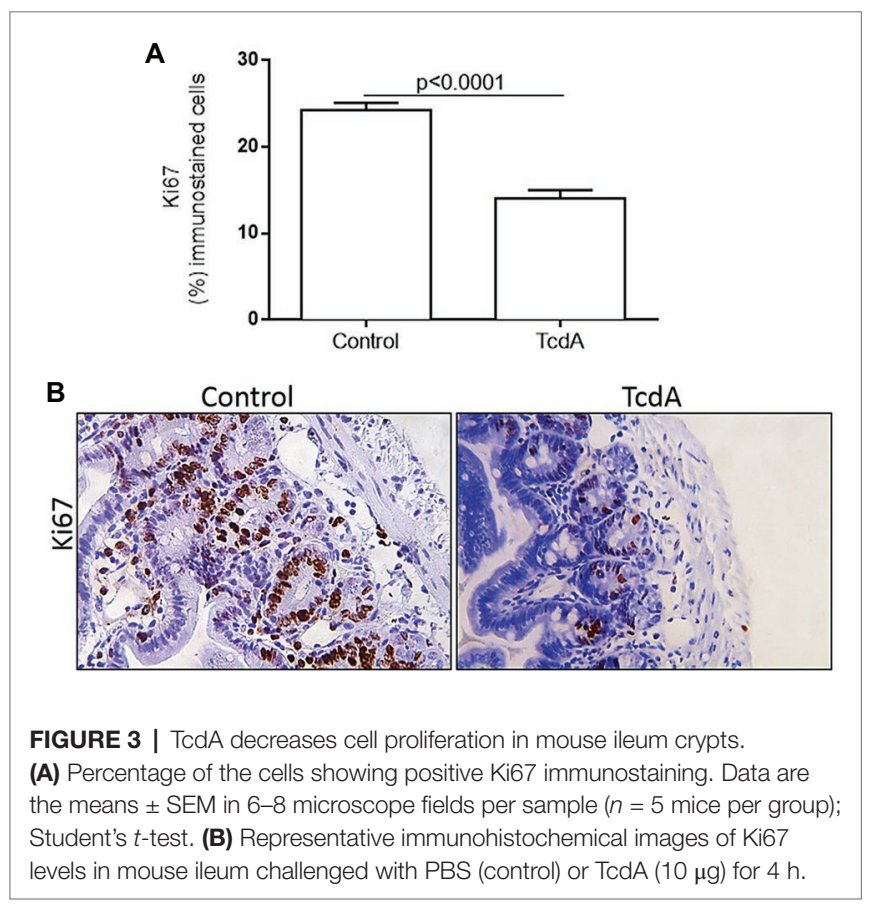

IECs, we asked whether upregulation of Rac1 through the transfection of pcDNA3-EGFP-Rac1-Q61L could recover the proliferation of epithelial (IEC-6) cells challenged with TcdA, which we evaluated by immunostaining Ki67, which is a marker of cell proliferation. As shown in Figures 6A,B, neither Rac1 upregulation nor exposure to Wnt3a-CM affected the TcdAinduced inhibition of IEC-6 cell proliferation. However, the combination of Racl upregulation and Wnt3a-CM reversed the inhibitory effect of TcdA on IEC- 6 cell proliferation $(p<0.001$; Figures 6A,B).

\section{DISCUSSION}

Herein, we demonstrate that TcdA inhibits Wnt signaling in vivo by decreasing the translocation of $\beta$-catenin to the nucleus, and thus downregulating its target genes (c-MYC and cyclin D1). Through this pathway, TcdA was shown to inhibit intestinal crypt cell proliferation in a mouse model of $C$. difficile-induced disease-like ileitis despite Wnt3a upregulation observed in the crypts and lamina propria cells, which were insufficient to induce Wnt/ $\beta$-catenin activation. 

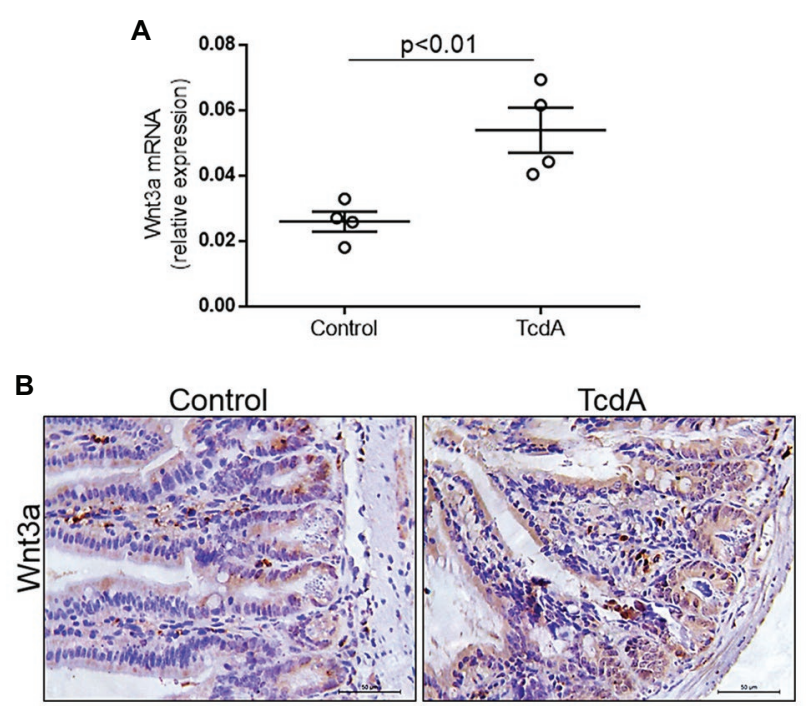

FIGURE 4 | TcdA increases Wnt3a expression in the mouse ileum. (A) Wnt3a mRNA expression in the ilea of the mice treated with PBS (control) or TcdA $(10 \mu \mathrm{g})$ for $4 \mathrm{~h}$ as evaluated by qPCR. Bars represent the means \pm SEM of five mice in each group. Student's $t$-test.

(B) Immunohistochemical images of Wnt3a expression in the ilea of mice treated with PBS (control) or TcdA $(10 \mu \mathrm{g})$ for $4 \mathrm{~h}$.

Our laboratory had previously demonstrated that TcdA inhibits the Wnt/ $\beta$-catenin pathway in IECs in vitro even when the cells are in the presence of the activator Wnt3a, an endogenous agonist; lithium chloride, a GSK3 $\beta$ inhibitor; and/or z-VAD-fmk, a nonspecific caspase inhibitor (Lima et al., 2014). Here, we demonstrated that Racl upregulation in the presence of Wnt3a-CM rescued TcdA-induced transcriptional inhibition (as demonstrated by the TOPflash/Renilla ratio), $\beta$-catenin nuclear translocation, cyclin D1 protein expression, and cell proliferation, implying that $\mathrm{TcdA}$ inhibits the Wnt/ $\beta$-catenin pathway in a Rac1-dependent manner.

As shown previously, the inhibitory effects of TcdA on the Wnt/ $\beta$-catenin pathway persist even in the presence of constitutively active $\beta$-catenin (Lima et al., 2014), suggesting that its inhibitory effect may be related to a defect in the process of $\beta$-catenin translocation to the nucleus, a process in which Rac-1 has been shown to play a crucial role (Buongiorno et al., 2008; Wu et al., 2008, 2009; Jamieson et al., 2015). Rac1 activates JNK, which in turn phosphorylates $\beta$-catenin, promoting its translocation to the nucleus (Wu et al., 2008).

Although Rac1 mRNA expression is not modified by TcdA, as shown in Supplementary Figure 1, it is well-known that TcdA, as well as TcdB, glucosylates Rho GTPases, such as, RhoA/B/C, Rac1/2, and Cdc42 promote Rac1 inactivation, decreasing the level of the active Racl isoform in the cytoplasm, and thus impeding its biological function (Reineke et al., 2007; Gerhard et al., 2008; Genisyuerek et al., 2011; Chen et al., 2016).

Using a promoter of the active pcDNA3-EGFP-Rac1-Q61L plasmid to upregulate Rac1 in IEC-6 cells (as shown in Supplementary Figure 3), we found that an increase in constitutively active Rac1 reverses both the inhibition of $\beta$-catenin translocation to the nucleus and the decrease in IEC-6 cell proliferation induced by TcdA in an extracellular Wnt3a-dependent manner. These data suggest that inhibition of the Wnt/ $\beta$-catenin signaling pathway promoted by $\operatorname{Tcd} A$ is a consequence of Racl glucosylation and inactivation by this toxin. The effect of EHop-016, a Rac inhibitor, on cell proliferation in mammary tumor growth reinforces our hypothesis (Montalvo-Ortiz et al., 2012). In agreement with our data, a previous report demonstrated that a dominantnegative Rac1 mutant drastically inhibits Wnt signaling in colon cancer followed by a decrease in its target gene transcription (Esufali and Bapat, 2004). Moreover, in Drosophila embryos, the deletion of RacGAP50C, a gene that negatively regulates Rac1, promoted the activation of $\mathrm{Wnt} / \beta$-catenin (Jones and Bejsovec, 2005). Rac1 also plays an important role in the phosphorylation of LRP5/6, a coreceptor required for FZD activation by Wnt proteins, in a PIP2-dependent manner (Schlessinger et al., 2009). PIP2 synthesis requires PIP4K and PIP5K, which are activated by Rho and Rac1 (Schlessinger et al., 2009). It is possible that inactivation of Rac1 by TcdA affects different stages of Wnt/ $\beta$-catenin signaling, but further investigations are needed to determine the exact stages affected.

TcdA and TcdB can act in different Rho proteins, but previous study suggested that Racl, rather than RhoA or Cdc42, is crucial for the cytopathic effects induced by TcdA and TcdB (Halabi-Cabezon et al., 2008). Although, we may not exclude the role of other Rho proteins, rather than Rac1, on TcdA inhibitory effect on Wnt/ $\beta$-catenin signaling pathway, the reversion of this effect by Racl upregulation suggests that Racl is a main mediator in this inhibition. In addition, we cannot exclude the involvement of additional mechanisms to modulate the activity of Racl in the present study, considering that specific modification at a single threonine residue in the small GTPases leads these important key players of several signaling pathways to their functional inactivation. TcdA and TcdB glucosylate $\operatorname{Rac} 1 / \mathrm{Cdc} 42$ at threonine-35 and RhoA, decreasing their active levels into the cells (Halabi-Cabezon et al., 2008; Schoentaube et al., 2009; Genth et al., 2018).

Racl involvement in TcdB-induced cytopathic effects in epithelial cells has been demonstrated (Halabi-Cabezon et al., 2008). In turn, inactivation of Racl is involved in the cytotoxic effect of high concentrations of TcdB (Beer et al., 2018). However, in our investigation, the upregulation of constitutively active Rac1 alone, without a Wnt3a conditioned medium, did not rescue the antiproliferative effect of TcdA or the inhibition of $\beta$-catenin translocation, suggesting that these toxins may act by different mechanisms. In addition, whereas TcdB has been shown to inhibit the activity of the Wnt/ $\beta$-catenin signaling pathway by binding to the FZD-7 receptor expressed by cells in the colonic epithelium (Tao et al., 2016), thereby preventing its activation by Wnt3a, TcdA has not shown affinity for FZD2, FZD3, or FZD-7 (Gupta et al., 2017). Like TcdA, TcdB induces inactivation of Rho GTPases including Rac-1 (Halabi-Cabezon et al., 2008; 

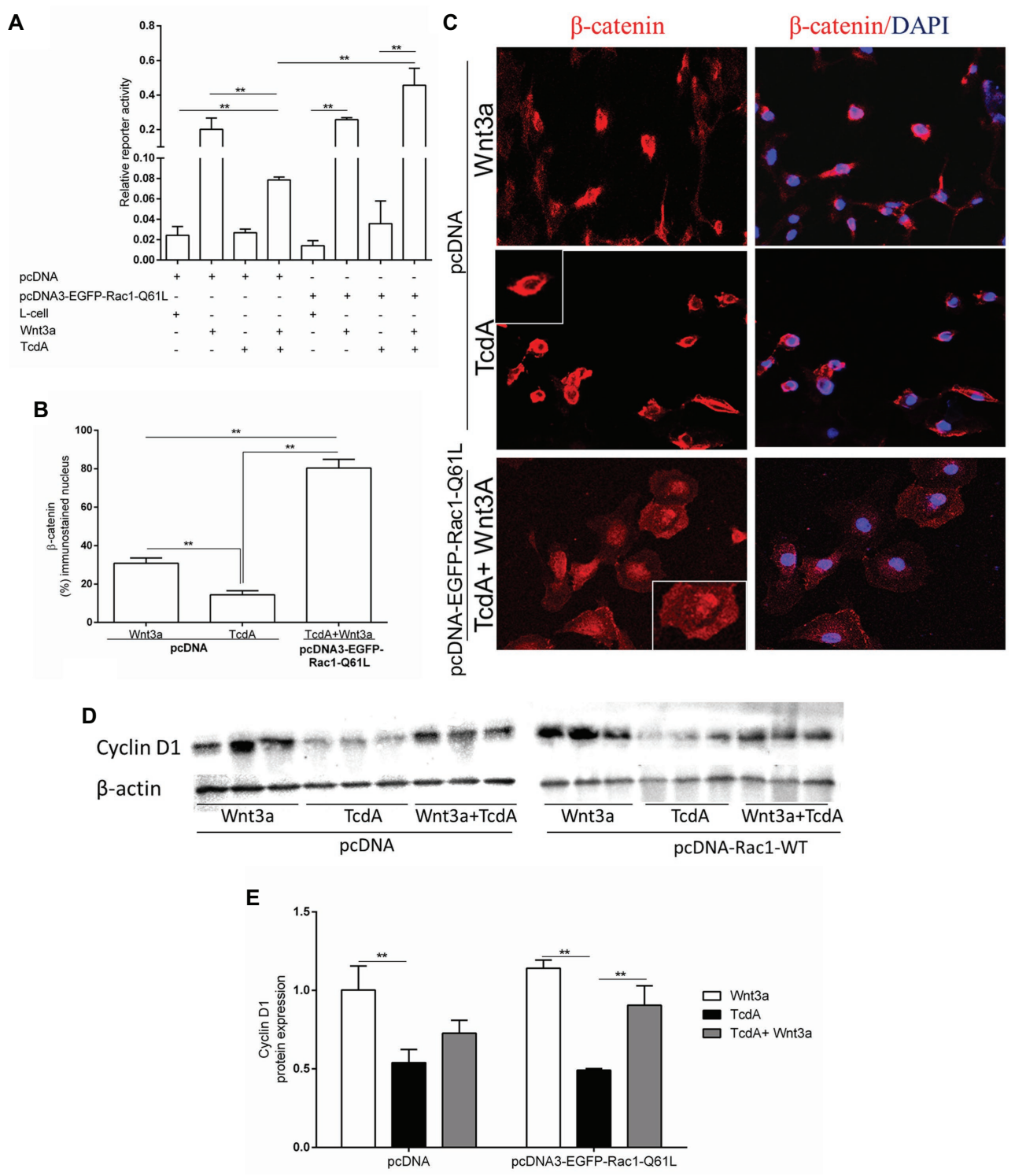

FIGURE 5 | Upregulation of Rac1 reverses the TcdA inhibitory effect on $\beta$-catenin nuclear translocation induced by Wnt3a in intestinal epithelial cells (IEC-6). (A) Relative reporter activity of $\beta$-catenin/T cell factor (TCF) signaling in the IEC-6 cells cotransfected with pcDNA (empty vector) or pcDNA3-EGFP-Rac1-Q61L, and TOPflash luciferase reporter constructs followed by incubation with TcdA ( $50 \mathrm{ng} / \mathrm{ml}$ ), Wnt3a-conditioned or L-cell medium for 24 h. Renilla luciferase constructs were used as an internal control for transfection efficiency. Bars represent the means \pm SEM $(n=5)$. One-way ANOVA, followed by Bonferroni's test, was used; ${ }^{\star \star} p<0.001$. (B) Percentage of cells showing positive $\beta$-catenin immunostaining in the nucleus. Data are the means \pm SEM. One-way ANOVA, followed by Bonferroni's test, was used; ${ }^{\star \star} p<0.001$. (C) Representative photomicrographs of immunostained $\beta$-catenin (red) and DAPI, a nuclear dye (blue), in IEC-6 cells transfected with pcDNA (empty vector) or pcDNA3-EGFP-Rac1-Q61L followed by $24 \mathrm{~h}$ incubation with TcdA (50 ng/ml) alone or Wnt3a-conditioned medium (Wnt3a-CM). (D) The WB bands of each group showing cyclin D1 and $\beta$-actin (a control protein) protein expression from lysed IEC-6 cells after $24 \mathrm{~h}$ of incubation. (E) Analysis of the relative band densities of cyclin D1 normalized to $\beta$-actin. Bars represent the means \pm SEM ( $n=5$ ). One-way ANOVA, followed by Bonferroni's test, was used; ${ }^{* *} p<0.001$.

Schoentaube et al., 2009; Genth et al., 2018), which should cause Wnt/ $\beta$-catenin signaling pathway inhibition. However, the investigation on $\mathrm{TcdB}$ effect in this pathway was not the aim of this study.

Wnt $/ \beta$-catenin pathway activation with subsequent recruitment of $\beta$-catenin into the nucleus results in epithelial cell proliferation due to the increased expression of key cell cycle proteins, such as cyclin D1 and c-MYC (Clevers, 2006;
Humphries and Wright, 2008). These protein expression levels were reduced by TcdA followed by a decrease in epithelial proliferation in the mouse ileum, as demonstrated in the present study. Consistently, TcdA critically affected three of the most important aspects of the intestinal mucosal repair process: epithelial cell migration, apoptosis, and cell proliferation (Brito et al., 2005). In addition, another report demonstrated that $\beta$-catenin- and TCF4-knockdown mice 


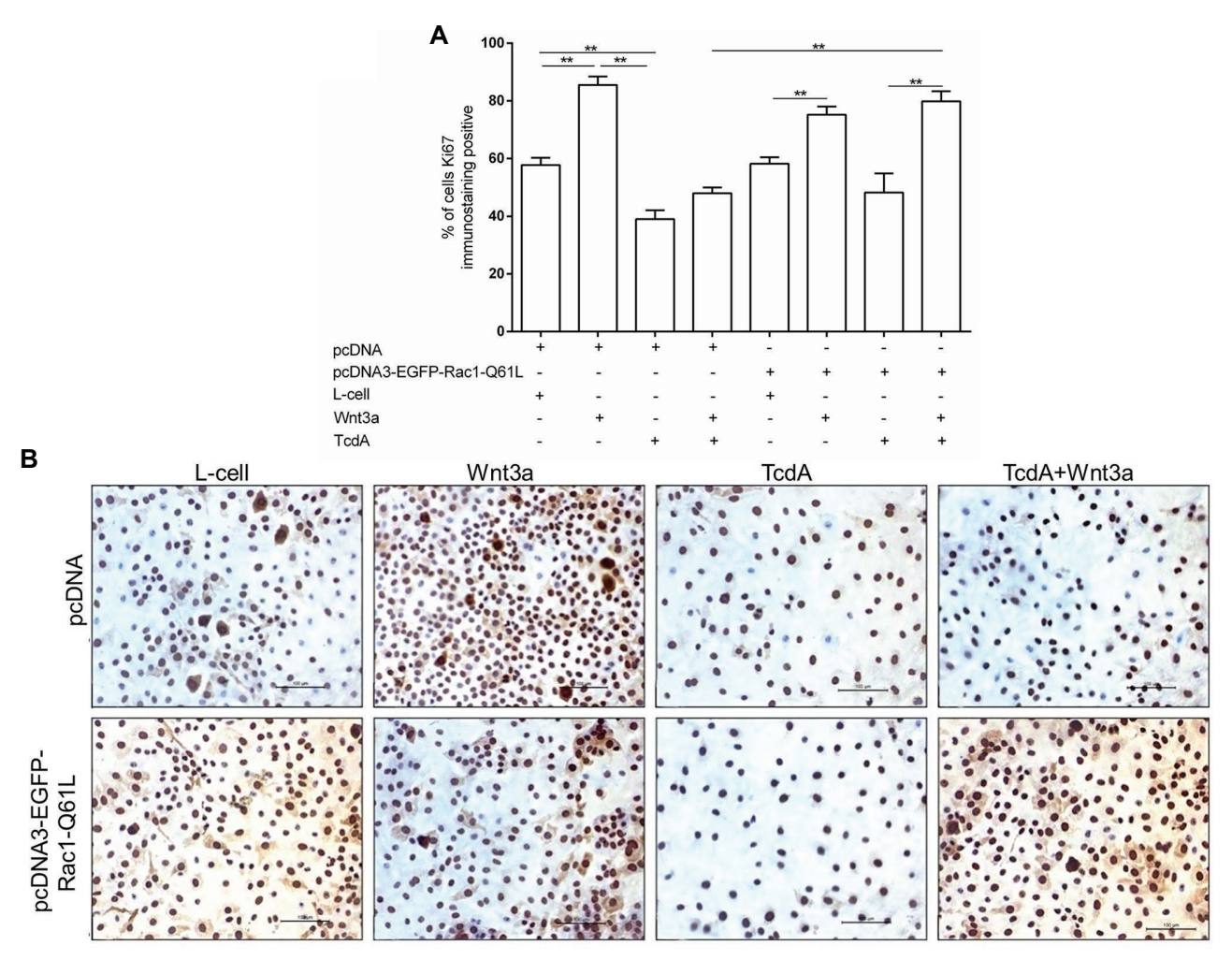

FIGURE 6 | Upregulation of Rac1 reverses the TcdA inhibitory effect on Wnt3a-induced proliferation of the IEC-6 cells. (A) Percentage of IEC-6 cells showing positive Ki67 immunostaining after being cotransfected with pcDNA (empty vector) or pcDNA3-EGFP-Rac1-Q61L upon incubation with TcdA (50 ng/ml), Wnt3a-CM or L-cell medium for $24 \mathrm{~h}$. Data are the means \pm SEM $(n=6)$. One-way ANOVA, followed by the Bonferroni's test, was used; ** $p<0.001$. (B) Representative immunohistochemical images of the Ki67-immunostained IEC-6 cells transfected with pcDNA (empty vector) or pcDNA3-EGFP-Rac1-Q61L, followed by $24 \mathrm{~h}$ incubation with TcdA alone or Wnt3a-CM or L-cell medium.

exhibited decreased cell proliferation in intestinal crypts (Tao et al., 2014). Multiple pathways, including the Wnt/ $\beta$ catenin pathway and the expression of their target genes, are essential for maintaining epithelial barrier function and epithelial cell repair after injury. In C. difficile infection, the accumulation of $\mathrm{TcdA}$ and $\mathrm{TcdB}$ is associated with Wnt/ $\beta$-catenin pathway inhibition, although this downregulation is induced, at least in part, by different mechanisms, and together with pro-inflammatory cytokine production within the intestinal mucosa, this accumulation likely results in intestinal epithelial stem cell niche degeneration and suppression of repair (Farin et al., 2014; Leslie et al., 2015; Liu et al., 2019).

Interestingly, the inhibition of $\beta$-catenin translocation to the nucleus and the subsequent downregulation of $\beta$-catenin target genes were maintained even during TcdA-induced Wnt3a upregulation in the mouse ileum, suggesting that a TcdA intracellular mechanism is involved in its inhibitory effect on the Wnt/ $\beta$-catenin pathway. According to our data, increased Wnt3a expression was found in patients with ulcerative colitis compared to the level found in patients with noninflammatory bowel disease, but no difference was found in the expression of a panel of Wnt target genes (You et al., 2008). Although Paneth cells are an important source of Wnt ligands (Wnt3a) needed to sustain the self-renewal of intestinal epithelial stem cells, Paneth cells are impaired upon C. difficile infection (Liu et al., 2019). In the present study, the expression of Wnt3a was found mainly in lamina propria cells, suggesting that immuneinduced inflammatory cells are involved in the release of Wnt3a. According to this premise, several studies have reported the synthesis of Wnt ligands by macrophages, which are related to mucosal healing (Loilome et al., 2014). There is a possibility that increased if Wnt3a upregulation may result in simultaneous upregulation of Wnt3a inhibitors, such as DKK and SFRP, which in turn additionally could contribute to pathway inhibition.

In addition to the importance of the clarification of this pathway inhibition mechanism by TcdA in C. difficile infection, targeting Rac-1 with TcdA, which resulted in the Wnt/ $\beta$-catenin pathway and cell proliferation inhibition, may be one strategy to control tumor growth. According to this hypothesis, new findings suggest that TcdA may be able to inhibit proliferation and apoptosis and partially reverse multidrug resistance in a human chronic myeloid leukemia cell line (Xi et al., 2018).

Taken together, our data suggest that Racl inactivation is one of the mechanisms behind the impairment of Wnt $/ \beta$-catenin 


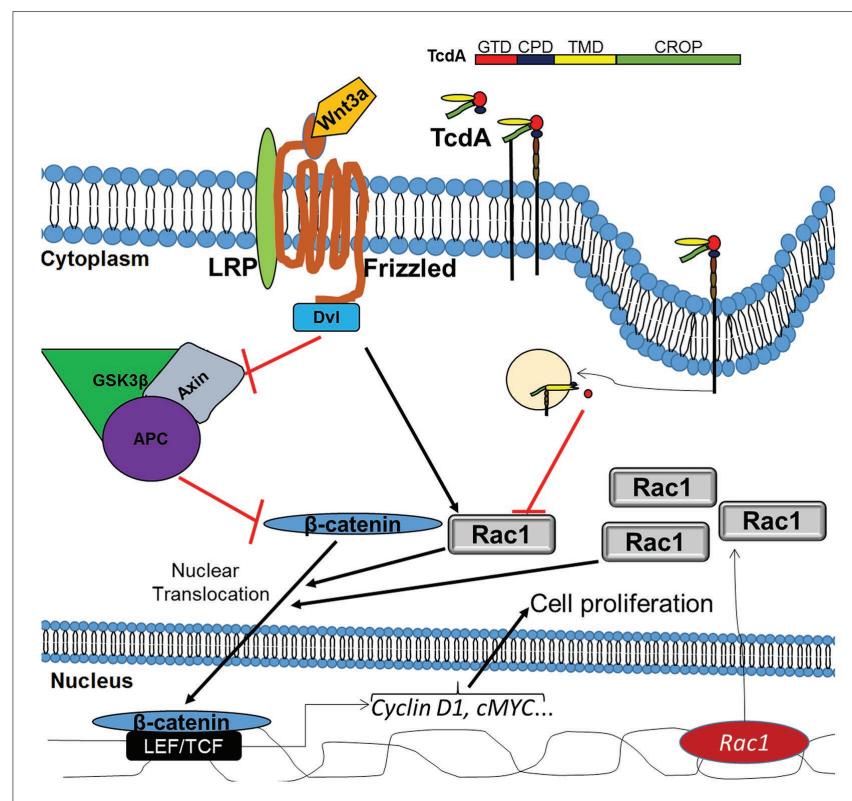

FIGURE 7 | Mechanism of inhibition of Wnt/ $\beta$-catenin signaling by TcdA. In IECs, Wnt3a binds to the frizzled (FZD) receptor and its coreceptor lymphoid enhancer factor (LRP), recruiting disheveled (Dvl), which in turn inhibits the adenomatous polyposis coli (APC)/glycogen synthase kinase 3 beta (GSK3 $\beta$ )/ Axin complex, which degrade $\beta$-catenin. Upon inhibition of the APC/GSK3 $\beta$ / APC complex, $\beta$-catenin accumulates in the cytoplasm and is translocated into the nucleus, with Rac1 serving as a promoter of this translocation, where it activates LEF/TCF to promote the transcription of target genes, such as cyclin D1 and $C M Y C$. Both cyclin D1 and CMYC are involved in the induction of cell proliferation. TcdA [composed of glucosyltransferase domain (GDT), cysteine protease domain (CPD), translocation membrane domain (TMD), and C-terminal combined repetitive oligopeptide (CROP)] binds to a cell receptor by CROP and is endocytosed. Then, GDT is released into the cytosol, where it inhibits Rac1, resulting in a decrease in $\beta$-catenin translocation to the nucleus with a consequent reduction in the genic expression of the target genes and cell proliferation. However, upregulation of Rac1, in the presence of Wnt3a activity, decreases TcdA-induced inhibition of Wnt3a/ $\beta$-catenin signaling and proliferation. APC, adenomatous polyposis coli; CPD, cysteine protease domain; CROPs, C-terminal combined repetitive oligopeptides; Dvl, disheveled; GSK3 $\beta$, glycogen synthase kinase 3 beta; GTD, glucosyltransferase domain; LEF, Iymphoid enhancer factor; LRP, low-density-lipoprotein-related protein; TCF, T cell factor protein; and TMD, translocation membrane domain.

signaling pathway by TcdA (Figure 7). The clarification of the involvement of Rac-1 in the mechanism of C. difficile TcdA inhibition reveals a potential target for future research on the modulation of Wnt/ $\beta$-catenin signaling for therapeutic interventions.

\section{REFERENCES}

Beer, L. A., Tatge, H., Reich, N., Tenspolde, M., Olling, A., Goy, S., et al. (2018). Early cell death induced by Clostridium difficile TcdB: uptake and Rac1-glucosylation kinetics are decisive for cell fate. Cell. Microbiol. 20:e12865. doi: $10.1111 / \mathrm{cmi} .12865$

Brito, G. A. C., Carneiro-Filho, B., Oriá, R. B., Destura, R. V., Lima, A. A. M., and Guerrant, R. L. (2005). Clostridium difficile toxin A induces intestinal epithelial cell apoptosis and damage: role of Gln and Ala-Gln in toxin A effects. Dig. Dis. Sci. 50, 1271-1278. doi: 10.1007/s10620-005-2771-x

Brito, G. A. C., Fujji, J., Carneiro-Filho, B. A., Lima, A. A. M., Obrig, T., and Guerrant, R. L. (2002). Mechanism of Clostridium difficile toxin A-induced apoptosis in T84 cells. J. Infect. Dis. 186, 1438-1447. doi: 10.1086/344729

\section{DATA AVAILABILITY STATEMENT}

All datasets generated for this study are included in the article/Supplementary Material.

\section{ETHICS STATEMENT}

The animal study was reviewed and approved by Federal University of Ceará Committee on the Ethical Treatment of Research Animals (CEUA. No. 2727150218).

\section{AUTHOR CONTRIBUTIONS}

CM designed and performed all the experiments, analyzed the data, wrote the manuscript, and helped in the acquisition of the data. GS, GF, and DP performed experiments and contributed to the data analysis. DC, RL, BL, and JA helped with the experimental design and the revision of the manuscript. $\mathrm{GB}$, the principal investigator for the grant and for constructing the experimental design, supervised the project and helped write the manuscript. All authors contributed to the article and approved the submitted version.

\section{FUNDING}

This work was supported by PRONEX/FUNCAP/CNPq of Brazil through grant PR2-0101-00060.01.00/15.

\section{ACKNOWLEDGMENTS}

The authors would like to thank for Flávia Araújo and Adalberto Junior technical assistance. In addition, the authors would like to thank for Federal University of Ceará for supporting the publication fee.

\section{SUPPLEMENTARY MATERIAL}

The Supplementary Material for this article can be found online at: https://www.frontiersin.org/articles/10.3389/fmicb.2020.01998/ full\#supplementary-material

Buongiorno, P., Pethe, V. V., Charames, G. S., Esufali, S., and Bapat, B. (2008). Racl GTPase and the Racl exchange factor Tiaml associate with Wnt-responsive promoters to enhance beta-catenin/TCF-dependent transcription in colorectal cancer cells. Mol. Cancer 7:73. doi: 10.1186/14764598-7-73

Chen, P., Tao, L., Liu, Z., Dong, M., and Jin, R. (2019). Structural insight into Wnt signaling inhibition by Clostridium difficile toxin B. FEBS J. 286, 874-881. doi: $10.1111 /$ febs.14681

Chen, S., Wang, H., Gu, H., Sun, C., Li, S., Feng, H., et al. (2016). Identification of an essential region for translocation of Clostridium difficile toxin B. Toxins 8:241. doi: 10.3390/toxins8080241

Clevers, H. (2006). Wnt/ $\beta$-catenin signaling in development and disease. Cell 127, 469-480. doi: 10.1016/j.cell.2006.10.018 
Daniels, D. L., and Weis, W. I. (2005). $\beta$-catenin directly displaces Groucho/ TLE repressors from Tcf/Lef in Wnt-mediated transcription activation. Nat. Struct. Mol. Biol. 12, 364-371. doi: 10.1038/nsmb912

D’Auria, K. M., Donato, G. M., Gray, M. C., Kolling, G. L., Warren, C. A., Cave, L. M., et al. (2012). Systems analysis of the transcriptional response of human ileocecal epithelial cells to Clostridium difficile toxins and effects on cell cycle control. BMC Syst. Biol. 6:2. doi: 10.1186/1752-0509-6-2

De Araújo Junqueira, A. F. T., Martins Dias, A. A., Lima Vale, M., Turco Spilborghs, G. M. G., Siqueira Bossa, A., Bezerra Lima, B., et al. (2011). Adenosine deaminase inhibition prevents Clostridium difficile toxin A-induced enteritis in mice. Infect. Immun. 79, 653-662. doi: 10.1128/IAI.01159-10

Esufali, S., and Bapat, B. (2004). Cross-talk between Racl GTPase and dysregulated Wnt signaling pathway leads to cellular redistribution of $\beta$-catenin and TCF/LEF-mediated transcriptional activation. Oncogene 23, 8260-8271. doi: 10.1038/sj.onc. 1208007

Farin, H. F., Karthaus, W. R., Kujala, P., Rakhshandehroo, M., Schwank, G., Vries, R. G. J., et al. (2014). Paneth cell extrusion and release of antimicrobial products is directly controlled by immune cell-derived IFN- $\gamma$. J. Exp. Med. 211, 1393-1405. doi: 10.1084/jem.20130753

Gao, L., Chen, B., Li, J., Yang, F., Cen, X., Liao, Z., et al. (2017). Wnt/ $\beta$-catenin signaling pathway inhibits the proliferation and apoptosis of U87 glioma cells via different mechanisms. PLoS One 12:e0181346. doi: 10.1371/journal. pone. 0181346

Genisyuerek, S., Papatheodorou, P., Guttenberg, G., Schubert, R., Benz, R., and Aktories, K. (2011). Structural determinants for membrane insertion, pore formation and translocation of Clostridium difficile toxin B. Mol. Microbiol. 79, 1643-1654. doi: 10.1111/j.1365-2958.2011.07549.x

Genth, H., Junemann, J., Lämmerhirt, C. M., Lücke, A. -C., Schelle, I., Just, I., et al. (2018). Difference in mono-o-glucosylation of Ras subtype GTPases between toxin A and toxin B from Clostridioides difficile strain 10463 and lethal toxin from Clostridium sordellii strain 6018. Front. Microbiol. 9:3078. doi: $10.3389 /$ fmicb.2018.03078

Gerhard, R., Nottrott, S., Schoentaube, J., Tatge, H., Olling, A., and Just, I. (2008). Glucosylation of Rho GTPases by Clostridium difficile toxin A triggers apoptosis in intestinal epithelial cells. J. Med. Microbiol. 57, 765-770. doi: $10.1099 / \mathrm{jmm} \cdot 0.47769-0$

Gough, N. R. (2012). Focus issue: Wnt and $\beta$-catenin signaling in development and disease. Sci. Signal. 5:eg2. doi: 10.1126/scisignal.2003044

Gupta, P., Zhang, Z., Sugiman-Marangos, S. N., Tam, J., Raman, S., Julien, J. P., et al. (2017). Functional defects in Clostridium difficile TcdB toxin uptake identify CSPG4 receptor-binding determinants. J. Biol. Chem. 292, 17290-17301. doi: $10.1074 /$ jbc.M117.806687

Halabi-Cabezon, I., Huelsenbeck, J., May, M., Ladwein, M., Rottner, K., Just, I., et al. (2008). Prevention of the cytopathic effect induced by Clostridium difficile toxin B by active Rac1. FEBS Lett. 582, 3751-3756. doi: 10.1016/j. febslet.2008.10.003

Humphries, A., and Wright, N. (2008). Colonic crypt organization and tumorigenesis. Nat. Rev. Cancer 8, 415-424. doi: 10.1038/nrc2392

Jaffe, A. B., and Hall, A. (2005). Rho GTPases: biochemistry and biology. Annu. Rev. Cell Dev. Biol. 21, 247-269. doi: 10.1146/annurev. cellbio.21.020604.150721

Jamieson, C., Lui, C., Brocardo, M. G., Martino-Echarri, E., and Henderson, B. R. (2015). Racl augments Wnt signaling by stimulating $\beta$-catenin-lymphoid enhancer factor-1 complex assembly independent of $\beta$-catenin nuclear import. J. Cell Sci. 128, 3933-3946. doi: 10.1242/jcs.167742

Jones, W. M., and Bejsovec, A. (2005). RacGap50C negatively regulates wingless pathway activity during Drosophila embryonic development. Genetics 169, 2075-2086. doi: 10.1534/genetics.104.039735

Kimelman, D., and $\mathrm{Xu}, \mathrm{W}$. (2006). $\beta$-catenin destruction complex: insights and questions from a structural perspective. Oncogene 25, 7482-7491. doi: 10.1038/ sj.onc. 1210055

Kumar, A., Zloza, A., Moon, R. T., Watts, J., Tenorio, A. R., and Al-Harthi, L. (2008). Active $\beta$-catenin signaling is an inhibitory pathway for human immunodeficiency virus replication in peripheral blood mononuclear cells. J. Virol. 82, 2813-2820. doi: 10.1128/jvi.02498-07

Leslie, J. L., Huang, S., Opp, J. S., Nagy, M. S., Kobayashi, M., Young, V. B., et al. (2015). Persistence and toxin production by Clostridium difficile within human intestinal organoids result in disruption of epithelial paracellular barrier function. Infect. Immun. 83, 138-145. doi: 10.1128/IAI.02561-14
Lica, M., Schulz, F., Schelle, I., May, M., Just, I., and Genth, H. (2011). Difference in the biological effects of Clostridium difficile toxin B in proliferating and non-proliferating cells. Naunyn Schmiedebergs Arch. Pharmacol. 383, 275-283. doi: 10.1007/s00210-010-0595-5

Lima, B. B., Fonseca, B. F., Amado, N., da Graça Amado, N., Lima, D. M., Ribeiro, R. A., et al. (2014). Clostridium difficile toxin A attenuates Wnt/ $\beta$ catenin signaling in intestinal epithelial cells. Infect. Immun. 82, 2680-2687. doi: 10.1128/IAI.00567-13

Liu, R., Moriggl, R., Zhang, D., Li, H., Karns, R., Ruan, H., et al. (2019). Constitutive STAT5 activation regulates paneth and paneth-like cells to control Clostridium difficile colitis. Life Sci. Alliance 2:e201900296. doi: 10.26508/lsa.201900296

Livak, K. J., and Schmittgen, T. D. (2001). Analysis of relative gene expression data using real-time quantitative PCR and the $2(-$ Delta Delta $\mathrm{C}(\mathrm{T}))$ method. Methods 25, 402-408. doi: 10.1006/meth.2001.1262

Loilome, W., Bungkanjana, P., Techasen, A., Namwat, N., Yongvanit, P., Puapairoj, A., et al. (2014). Activated macrophages promote Wnt $/ \beta$-catenin signaling in cholangiocarcinoma cells. Tumour Biol. 35, 5357-5367. doi: 10.1007/s13277-014-1698-2

Montalvo-Ortiz, B. L., Castillo-Pichardo, L., Hernández, E., Humphries-Bickley, T., De la Mota-Peynado, A., Cubano, L. A., et al. (2012). Characterization of EHop-016, novel small molecule inhibitor of Rac GTPase. J. Biol. Chem. 287, 13228-13238. doi: 10.1074/jbc.M111.334524

Pethe, V. V., Charames, G. S., and Bapat, B. (2011). Raclb recruits disheveled and $\beta$-catenin to Wnt target gene promoters independent of Wnt3A stimulation. Int. J. Oncol. 39, 805-810. doi: 10.3892/ijo.2011.1066

Reineke, J., Tenzer, S., Rupnik, M., Koschinski, A., Hasselmayer, O., Schrattenholz, A., et al. (2007). Autocatalytic cleavage of Clostridium difficile toxin B. Nature 446, 415-419. doi: 10.1038/nature05622

Ring, A., Kim, Y. M., and Kahn, M. (2014). Wnt/catenin signaling in adult stem cell physiology and disease. Stem Cell Rev. Rep. 10, 512-525. doi: 10.1007/s12015-014-9515-2

Schlessinger, K., Hall, A., and Tolwinski, N. (2009). Wnt signaling pathways meet Rho GTPases. Genes Dev. 23, 265-277. doi: 10.1101/gad.1760809

Schoentaube, J., Olling, A., Tatge, H., Just, I., and Gerhard, R. (2009). Serine-71 phosphorylation of Racl/Cdc42 diminishes the pathogenic effect of Clostridium difficile toxin A. Cell. Microbiol. 11, 1816-1826. doi: 10.1111/ j.1462-5822.2009.01373.x

Steinhart, Z., and Angers, S. (2018). Wnt signaling in development and tissue homeostasis. Development 145:dev146589. doi: 10.1242/dev.146589

Subauste, M. C., Von Herrath, M., Benard, C. E., Chamberlain, C. E., Chuang, T. H., Chu, K., et al. (2000). Rho family proteins modulate rapid apoptosis induced by cytotoxic T lymphocytes and Fas. J. Biol. Chem. 275, 9725-9733. doi: $10.1074 /$ jbc. 275.13 .9725

Tao, J., Calvisi, D. F., Ranganathan, S., Cigliano, A., Zhou, L., Singh, S., et al. (2014). Activation of $\beta$-catenin and Yapl in human hepatoblastoma and induction of hepatocarcinogenesis in mice. Gastroenterology 147, 690-701. doi: 10.1053/j.gastro.2014.05.004

Tao, L., Zhang, J., Meraner, P., Tovaglieri, A., Wu, X., Gerhard, R., et al. (2016). Frizzled proteins are colonic epithelial receptors for C. difficile toxin B. Nature 538, 350-355. doi: 10.1038/nature19799

Tinoco-Veras, C. M., Santos, A. A. Q. A., Stipursky, J., Meloni, M., Araujo, A. P. B., Foschetti, D. A., et al. (2017). Transforming growth factor $\beta 1 / S M A D$ signaling pathway activation protects the intestinal epithelium from Clostridium difficile toxin A-induced damage. Infect. Immun. 85, e00430-e00517. doi: 10.1128/IAI.00430-17

Tortelote, G. G., Reis, R. R., de Almeida Mendes, F., and Abreu, J. G. (2017). Complexity of the Wnt $/ \beta$-catenin pathway: searching for an activation model. Cell. Signal. 40, 30-43. doi: 10.1016/j.cellsig.2017.08.008

Vega, F. M., and Ridley, A. J. (2008). Rho GTPases in cancer cell biology. FEBS Lett. 582, 2093-2101. doi: 10.1016/j.febslet.2008.04.039

Welsh, C. F., Liu, Y. Q., Roovers, K., Villanueva, J., Assoian, R. K., and Schwartz, M. A. (2001). Timing of cyclin D1 expression within G1 phase is controlled by Rho. Nat. Cell Biol. 3, 950-957. doi: 10.1038/ncb1101-950

Wennerberg, K., and Der, C. J. (2004). Rho-family GTPases: it's not only Rac and Rho (and I like it). J. Cell Sci. 117, 1301-1312. doi: 10.1242/jcs.01118

Wu, G., Huang, H., Abreu, J. G., and He, X. (2009). Inhibition of GSK3 phosphorylation of $\beta$-catenin via phosphorylated PPPSPXS motifs of Wnt coreceptor LRP6. PLoS One 4:e4926. doi: 10.1371/journal.pone.0004926 
Wu, X., Tu, X., Joeng, K. S., Hilton, M. J., Williams, D. A., and Long, F. (2008). Racl activation controls nuclear localization of $\beta$-catenin during canonical Wnt signaling. Cell 133, 340-353. doi: 10.1016/j.cell.2008.01.052

Xi, Y., Ma, Z., Zhang, H., Yuan, M., and Wang, L. (2018). Effects of Clostridiumï difficile toxin A on K562/A02 cell proliferation, apoptosis and multi-drug resistance. Oncol. Lett. 15, 4215-4220. doi: 10.3892/ol.2018.7921

You, J., Nguyen, A. V., Albers, C. G., Lin, F., and Holcombe, R. F. (2008). Wnt pathway-related gene expression in inflammatory bowel disease. Dig. Dis. Sci. 53, 1013-1019. doi: 10.1007/s10620-007-9973-3

Zhu, D., Sorg, J. A., and Sun, X. (2018). Clostridioides difficile biology: sporulation, germination, and corresponding therapies for C. difficile infection. Front. Cell. Infect. Microbiol. 8:29. doi: 10.3389/fcimb.2018.00029
Conflict of Interest: The authors declare that the research was conducted in the absence of any commercial or financial relationships that could be construed as a potential conflict of interest.

Copyright (c) 2020 Martins, Costa, Lima, Leitäo, Freire, Silva, Pacífico, Abreu and Brito. This is an open-access article distributed under the terms of the Creative Commons Attribution License (CC BY). The use, distribution or reproduction in other forums is permitted, provided the original author $(s)$ and the copyright owner(s) are credited and that the original publication in this journal is cited, in accordance with accepted academic practice. No use, distribution or reproduction is permitted which does not comply with these terms. 